\title{
O PENSAMENTO GEOGRÁFICO NO KITAB DE IDRISI E NA RIHLA DE BATTUTA: UMA REFLEXÃO EPISTEMOLÓGICA COMPARATIVA
}

\section{GEOGRAPHICAL THINKING IN KITAB OF IDRISI AND IN RIAT OF BATTUTA: A COMPARATIVE EPISTEMOLOGICAL REFLECTION}

\section{LA PENSÉE GÉOGRAPHIQUE DANS LE KITAB D'IDRISI ET DANS LE RIHLA DE BATTUTA: UNE RÉFLEXION ÉPISTEMOLOGIQUE COMPARATIVE}

\author{
Oswaldo Bueno Amorim Filho ${ }^{1}$ \\ Pontifícia Universidade Católica de Minas Gerais, Belo Horizonte, Brasil
}

\begin{abstract}
Resumo: O presente estudo procurou alcançar três objetivos maiores, todos de caráter epistemológico: o primeiro foi o de abordar com um novo olhar as contribuições de pensadores muçulmanos medievais ao desenvolvimento de vários domínios da geografia; o segundo foi o de buscar a confirmação da ideia de que os geógrafos do Islã medieval fizeram a ligação entre os gregos da Antiguidade e dos precursores, nos séculos XVII e XVIII, das grandes escolas clássicas europeias de geografia; o terceiro foi o de mostrar um outro aspecto até agora não contemplado, ou seja, a constatação de que, além de várias semelhanças e diferenças significativas, um estudo comparativo entre o Kitab de Idrisi e a Rihla de Battuta, permite identificar, já no Islã medieval, a presença, de um lado, de uma abordagem científica ou, pelo menos pré-científica (Idrisi) e, de outro, de um enfoque predominantemente corográfico, com forte influência religiosa e práticas que prenunciam algumas feições que podem ser encontradas nas geografias humanistas e culturais da atualidade (Battuta).
\end{abstract}

Palavras-chave: Kitab; Rihla; Epistemologia.

Abstract: This study has aimed at three main goals, all of them of epistemic nature: the first is to approach from a new point of view the contributions of medieval Muslim thinkers to different domains of Geography; the second was to try to confirm the idea that, most likely, the medieval geographers of Islam have made the connection between the Greeks from antiquity and the predecessors of 17th and 18th centuries' classic European schools of geography; the third goal is to show a not yet brought issue, that is the conclusion that, besides many significant similarities and differences, a comparative study between Idrisi's Kitab and Battuta's Rihla allows the identification, in medieval Islam, on the one hand, the presence of a scientific approach or, at least, a pre-scientific (Idrisi) one, and on the other hand of a corographic view, with strong religious influence and practices that can be found in current humanistic and cultural geographies (Battuta).

Keywords: Kitab; Rihla; Epistemology.

Resumé: Ce travail avait trois buts majeurs, tous à caractère épistémologique : le premier c'était de jeter un regard nouveau sur les contributions des penseurs musulmans médiévaux au développement de plusieurs domaines de la géographie ; le second c'était de chercher la confirmation de l'idée selon laquelle géographies de l'Islam médiéval ont fait la liaison entre les Grecs anciens et les précurseurs, aux XVIIe et XVIIIe siècles, des grandes écoles

\footnotetext{
${ }^{1}$ Professor titular aposentado da UFMG. Atualmente é professor do Programa de Pós-Graduação em Geografia (Tratamento da Informação Espacial) da Pontifícia Universidade Católica de Minas Gerais. E-mail: taitsonbueno@terra.com.br.
} 
classiques européennes de géographie; le troisième fut celui de montrer un autre aspect, peu exploré jusqu'aujourd'hui, c'est-à-dire en plus de plusieurs analogies et différences, une étude comparative entre le Kitab d'Idrisi et la Rihla de Battuta permet d'identifier, aussi la présence, d'un côté, d'un approche pré-scientifique (Idrisi) et, de l'autre, d'un approche éminemmant chorographique, sous une forte influence religieuse e avec quelques pratiques qui préfigurent certains traits qui peuvent être trouvés dans les géographies humanistes et culturelles d'aujourd'hui (Battuta).

Mots-clé: Kitab; Rihla; Épistémologie.

\section{INTRODUÇÃO}

As motivações que levaram à realização deste estudo são fundamentalmente epistemológicas, estando ligadas ao aprofundamento das reflexões sobre certos períodos da história da geografia que, depois de serem por muito tempo negligenciados por parte significativa da comunidade dos geógrafos, começam a ser objeto de crescente interesse dessa mesma comunidade e daquelas de campos de conhecimento afins.

As geografias desenvolvidas na Idade Média e no período moderno, que antecede imediatamente o das "Escolas Clássicas Européias", fizeram parte desses "ângulos mortos" da evolução do pensamento geográfico.

Para se ter uma ideia de como a geografia na Idade Média (em particular aquela produzida pelos geógrafos muçulmanos) era pouco valorizada pelos historiadores do pensamento geográfico, podem-se tomar como exemplos quatro consagradas histórias da geografia.

- na Histoire de la Géographie (René Clozier, 1972), de um total de 128 páginas, 10 são dedicadas à geografia na Idade Média e, destas, uma página e meia à geografia dos árabes;

- na, também, Histoire de la Géographie (Paul Claval, 1995), do total de 128 páginas, 7 páginas e meia cobrem a geografia medieval, das quais 2 se voltam para a geografia árabe;

- em All Possible Worlds - A history of geographical ideas (Geofrey J. Martin, 2005), do total de 605 páginas, 22 dizem respeito à geografia medieval e, destas, 5 à geografia do mundo muçulmano;

- finalmente, em Geography - History and Concepts: A Student Guide (Arild Holt-Jensen, 2009), de 264 páginas, apenas 2 são dedicadas à geografia na Idade Média e, destas, menos de uma página aos geógrafos árabes. 
Algumas tendências, porém, indicam que uma mudança vem ocorrendo a esse respeito no mundo e no Brasil, sobretudo relacionada com os anos próximos ao de 2004, quando se comemorou, mais um centenário do nascimento do viajante, geógrafo e aventureiro marroquino, Ibn Battuta.

Um lugar de destaque entre as pesquisas acadêmicas brasileiras sobre a história e a geografia árabe-muçulmanas medievais é ocupado pela tese que a Professora Beatriz Bissio defendeu em 2008 na Universidade Federal Fluminense, onde foi orientada pela Professora Vânia Leite Fróes ${ }^{2}$. Esta tese se transformou em um livro com o título "O mundo falava árabe - A civilização árabe-islâmica clássica através da obra de Ibn Khaldun e Ibn Battuta", publicado em 2012, pela Editora Civilização Brasileira, livro que, embora com objetivos diferentes daqueles do presente trabalho, consultaremos mais de uma vez.

Nosso texto busca, primeiramente, compreender o processo histórico - espacial bastante rápido para a época - de transformação de uma sociedade periférica e fragmentada geograficamente, como a dos habitantes da Península Arábica pré-islâmica, em uma civilização (o Islã, entre os séculos IX e XIV) que tem sido considerada pelos historiadores como a mais avançada de seu tempo. Em seguida, este estudo quer mostrar, com base em critérios e categorias epistemológicos, que a geografia dos muçulmanos pode, efetivamente, ser considerada como a principal "ponte" entre os geógrafos da Grécia antiga e os da Europa moderna. Finalmente, será elaborada uma epistemologia comparativa do Kitab de Idrisi (século XII) e da Rihla de Battuta (século XIV), entre outras finalidades para reforçar a crença de que as abordagens dos geógrafos sempre tiveram, pelo menos, duas grandes vertentes: uma delas tem buscado sempre ser científica, sistemática, conceitual, matemática, explicativa e, por isso, seu caráter é mais hermético e seus leitores quase sempre da academia; a outra, menos rigorosa, mais descritiva, mais subjetiva, podendo chegar a ser literária e, portanto, artística. Assim, mostra-se menos sistemática e generalizável, mas, por outro lado, é a que mais alcance popular possui.

\section{A GEOGRAFIA MUÇULMANA COMO "PONTE" ENTRE OS GEÓGRAFOS DA GRÉCIA ANTIGA E OS DA EUROPA MODERNA}

O contexto histórico e geográfico no qual surge e se desenvolve originalmente a religião islâmica, no século VII da era cristã, era marcado por vários tipos de obstáculos e

\footnotetext{
${ }^{2}$ Os dois volumes originais da tese de Beatriz Bissio podem ser consultados, de acordo com a própria autora, no site da UFF: [http://www.historia.uff.br/stricto/tese-2008-Bissio-Beatriz-Juana-S.pdf]
} 
dificuldades, inicialmente ligados à geografia física. Essas condições naturais são, em seus aspectos mais gerais descritas de maneira sintética por Joseph Burlot:

O Islã nasce numa região à margem dos grandes impérios que se sucederam no Oriente Próximo, durante a Antiguidade: a Arábia ("Ilha árabe) é um verdadeiro subcontinente rodeado de mar por três lados e cortado do mundo asiático ocidental pelo deserto. Ela se divide em três zonas orientadas no sentido norte-sul: a Tihama, baixa planície litoral, que se estende ao longo do mar Vermelho; o Hedjaz ("barreira"), autêntica muralha, do qual certos cumes ultrapassam os dois mil metros; o Nejd, vasto planalto inclinado para o golfo Pérsico e, por vezes, recoberto de imensas dunas, como no Nefud e no Rubal-Khali ("o quadrante vazio"), um dos mais terríveis desertos do mundo. As montanhas do Iémen e do Hadramaut fecham a península ao sul (BURLOT, p. 13, 1990).

Sobre as características gerais dessas populações presentes na Península dos Árabes, a descrição feita por Albert Hourani é a seguinte:

Entre os grandes impérios do norte e os reinos do mar Vermelho, ficavam terras de uma espécie diferente. A maior parte da península Arábica era estepe ou deserto, com oásis isolados contendo água suficiente para cultivo regular. Os habitantes falavam vários dialetos do árabe e seguiam diferentes estilos de vida. Alguns eram nômades criadores de camelos, carneiros ou cabras, dependendo dos escassos recursos de água do deserto; eram tradicionalmente conhecidos como beduínos. Outros eram agricultores estabelecidos, cuidando de suas safras ou palmeiras nos oásis, ou então comerciantes e artesãos em pequenos vilarejos que sediavam feiras. (...) $\mathrm{O}$ equilíbrio entre povos nômades e sedentários era precário. Embora fossem uma minoria da população, eram os nômades dos camelos, móveis e armados, que, juntamente com os mercadores das aldeias, dominavam os lavradores e artesãos. (...) Não eram controlados por um poder de coerção estável, mas liderados por chefes que pertenciam a famílias em torno das quais se reuniam grupos de seguidores mais ou menos constantes, manifestando sua coesão e lealdade no idioma da ancestralidade comum: tais grupos são em geral chamados de tribos (HOURANI, 1991/1994, p. 26).

Peter N. Stearns, estudioso da história do Islã, elaborou um síntese, com grande poder de evocação, sobre a Arábia antes da Islamização:

A ARÁBIA ANTES DO PROFETA - A Arábia antes do nascimento de Maomé tinha sido uma região isolada e economicamente subdesenvolvida. A península Arábica tem algo como 1/3 do território continental dos Estados Unidos. Grande parte da terra é árida e deserta, a pluviosidade é escassa, a vegetação pobre e apenas uma pequena parte da terra presta-se ao cultivo. No norte da região, vários reinos árabes eram capazes de estabelecer contatos com os impérios Bizantino e Sassânida desde o século V de nossa era. No sul, pequenos reinos árabes, inclusive Sabá (Sheba), eram antigos centros da civilização arábica. Mas, no interior, dotado de poucos oásis, a vida nômade era a única forma de existência bem sucedida (STEARNS, 2011, p. 2, em http://history-world.org/Islam.htm).

Além dessas condições naturais difíceis, a Península Arábica era habitada por tribos quase sempre em guerra entre si e compostas de populações com grande número de 
analfabetos. Apesar dessas dificuldades, essas tribos foram unificadas e organizadas administrativa e militarmente, tendo realizado dois grandes feitos. $\mathrm{O}$ primeiro deles é a expansão da presença islâmica até à Índia, na direção leste e, para oeste, até a borda atlântica do Maghreb. A este respeito, assim se pronunciou o pensador H. G. Wells:

E quando Maomé morreu, Abu Bakr se tornou califa (sucessor) e, com a fé que move montanhas, dedicou-se com simplicidade e sensatez a organizar a subjugação de todo o mundo em nome de Alá - com pequenos exércitos de 3 ou 4 mil árabes... Segue-se agora o processo de conquista mais espantoso de toda a história de nossa raça (WELLS, 1920/2011, p. 206 e 207).

Em termos intelectuais e científicos, e em não mais do que três séculos, os pensadores árabes e de outros povos Islamizados serão capazes de deixar o atraso milenar que lhes era comum, para tornar-se a comunidade culturalmente mais avançada do mundo, em meados da Idade Média. E como se deu tão extraordinária metamorfose?

Entre os séculos VII e XII, dos vastos territórios islamizados da Ásia centromeridional às bordas mais ocidentais da península Ibérica e do Marrocos, dezenas de cidades se desenvolveram e algumas se tornaram grandes centros científicos e culturais: Damasco, Cairo, Tunis, Fez, Granada, Sevilha, Córdoba e, particularmente, Bagdá.

Com a chegada da dinastia Abássida (nome proveniente de Al-Abbas, tio paterno e seguidor fiel do Profeta) ao Califado, dois acontecimentos capitais tiveram consequências numerosas sobre o futuro do Islã, como um todo, e sobre a comunidade científica e cultural em geral. Abu Jafar Al-Mansur (no poder entre 754 e 775), um dos primeiros califas dessa dinastia, decide transferir a capital do Califado de Damasco para Bagdá, construindo aí uma nova cidade, que logo se torna uma verdadeira metrópole para os muçulmanos do Oriente. Este califa também lança, no final do século VIII, os fundamentos de um ambicioso projeto de longo prazo, que só alcançaria sua maturidade na primeira metade do século IX, com o califa Al-Mamun. Jonathan Lyons assim descreve a opção de Al-Mansur:

Protegido pelos muros duplos e portões fortificados de sua nova cidade na margem ocidental do Tigre, o enérgico Al-Mansur resolveu transformar seus domínios díspares numa superpotência científica e garantir o futuro dos abássidas associando seu novo Estado às grandes tradições clássicas que existiram ante dele. [...] Para acomodar a vasta escala do trabalho necessário para traduzir, copiar, estudar e guardar o volume crescente de textos persas, sânscritos, e gregos, Al-Mansur criou uma biblioteca real baseada nas dos grandes príncipes persas. Era preciso também espaço de trabalho, suporte administrativo e auxílio financeiro para o pequeno exército de eruditos que assumiria essas tarefas e depois as usaria de forma criativa e original. Essa foi a origem do que ficou conhecido em árabe como a Bayt Al-Hikma, ou Casa da Sabedoria [...]. Ao longo do tempo, a Casa da Sabedoria veio a abranger um escritório de traduções, uma biblioteca e repositório de livros e 
uma academia que contava com eruditos e intelectuais de todo o império (LYONS, 2009/2011, p. 87 e 88).

Os efeitos desse "embrião de academia" logo se fizeram sentir, primeiramente entre os árabes que, antes dos séculos VIII e IX, não possuíam trabalhos filosóficos e científicos que pudessem se assemelhar aqueles dos gregos, realizados cerca de 1.000 anos antes. Lyons continua, a respeito:

Ao longo de 150 anos, os árabes traduziram todos os livros gregos disponíveis de ciência e filosofia. O árabe substituiu o grego como língua universal da pesquisa científica. A educação superior ficou cada vez mais organizada no início do século IX e a maioria das principais cidades muçulmanas tinha algum tipo de universidade (LYONS, 2009/2011, p. 90).

No que diz respeito à geografia, a análise dos textos produzidos pelos geógrafos muçulmanos, a partir dos séculos VIII e IX, torna evidente a presença de uma forte influência dos gregos, desde Homero até Ptolomeu. Paul Claval estabelece assim esta conexão:

Os árabes dispunham, como todos os povos nômades, de uma rica tradição de observação do meio, de conhecimento dos lugares e da orientação geográfica, mas eles eram puramente orais. Eles ignoravam ciência e filosofia. Após a Conquista, seu poder se exerce no Próximo e no Médio Orientes sobre populações dominadas por elites urbanizadas bizantinas ou siríacas. Eles descobrem, por intermédio delas, a riqueza do pensamento grego. As traduções se multiplicam em Bagdá, no Iraque, sob o Califado Abássida, nos séculos VIII e IX. A geografia árabe desabrocha verdadeiramente de 800 a 1050; o uso do árabe, é, então, generalizado, mesmo entre os autores originários da Pérsia ou da Ásia Central (CLAVAL, 1995, p. 20 e 21).

A principal contribuição dos geógrafos da Grécia clássica para o pensamento geográfico foi, certamente, a unificação epistemológica de contribuições numerosas e diferenciadas. Este papel de unificadores foi desempenhado por autores como Eratóstenes, Ptolomeu e, especialmente, Estrabão. Este último, na obra 'Geografia', divide todo o conjunto da contribuição grega clássica em dois grandes eixos, interligados estruturalmente: geografia geral e geografia especial, esta última sendo igualmente denominada corografia. De acordo com J. García Blanco, um dos tradutores da geografia de Estrabão para o espanhol:

Estrabón distingue dos partes fundamentales, una geografía general y una geografía regional o corografía: la tarea de la geografía es de 'exponer en primer lugar nuestro mundo habitado, sus dimensiones, su figura, su naturaleza y su relación respecto a la tierra entera, pues ésta es la tarea propia del geógrafo. Después debe dar la explicación conveniente de cada una de las regiones, tanto terrestres como marítimas, añadiendo cuanto no haya sido suficientemente tratado por nuestros predecesores, especialmente los considerados los mejores en estos temas (BLANCO, 1991, p. 109). 
Esta antiga divisão da geografia, presente na obra de Estrabão, é sucessivamente retomada por alguns geógrafos muçulmanos medievais e, desde o século XVIII, por vários geógrafos ocidentais, entre eles: Verenius, Kant, Ritter, von Richthofen, Hettner; Vidal, Brunhes, de Martonne, Baulig, Clozier, Cribier, Drain e Durand-Dastès, Brunet, Meynier, George; Mackinder, Hartshorne, etc. Apenas para se ter uma ideia do que tais autores entendem por geografia geral e geografia especial ou regional, alguns exemplos foram escolhidos:

- Varenius, em meados do século XVII, dizia que:

Nós dividimos a Geografia em Geral e Especial, ou Universal e Particular. [...]. Nós chamamos universal a geografia que considera a Terra toda em geral e explica suas propriedades, sem considerar áreas particulares; mas, a Geografia Especial ou Particular descreve a constituição e a situação de cada área individual em si mesma e pode subdividir-se em Corográfica que descreve áreas de uma extensão considerável, ou Topográfica, que fornece uma visão de algum lugar, ou pequena porção da Terra (VARENIUS, tradução em 1734 da obra original de 1650, p. 2).

- Ferdinand von Richthofen, interpretado pelo geógrafo japonês Yamato KASAI, pensava que:

A geografia pode ser abordada através da mais detalhada investigação das menores áreas, assim como através do estudo comparativo em áreas maiores. Assim, há duas abordagens conforme sejam as áreas ou as coisas e fenômenos o objeto primordial de estudo. A primeira é basicamente descritiva e corresponde à geografia especial ("beschreiben oder spezielle Geographie"), a segunda é abstrata em função da unidade e da inferência e corresponde à geografia geral (analytische oder allgemeine Geographie). A primeira é sintética, a última é analítica (KASAI, 1975, p. 97 e 98).

- René Clozier, em 1942 e na mesma obra reeditada pela $5^{\text {a }}$ vez em 1971, afirmava:

A geografia geral se esforça no sentido de compreender o que há de permanente, de regular nos fatos terrestres, de aproximar tais fatos, de esclarecer uns em relação aos outros e de explicar sua condição. Cada fenômeno, quer se trate dos rios ou dos habitantes, das correntes marinhas ou das migrações humanas, das associações vegetais ou dos estabelecimentos industriais, deve ser considerado não somente em si mesmo, mas como parte de um todo; este sentido da repetição regular dos fenômenos de superfície, de sua comparação, está na base da explicação geográfica. [...] As combinações locais dos fatos estudados pela geografia geral são de competência da geografia regional. Cada região tem sua fisionomia própria; a paisagem atual não depende somente do relevo; ela resulta também da vegetação, cujas formas e cujo arranjo traduzem as influências climáticas e humanas, e de todas as marcas deixadas pelo homem, ao longo de suas tentativas para estruturar sua vida e organizar sua atividade. A geografia regional é, portanto, uma proteção contra o espírito de sistema da geografia geral (CLOZIER, 1942/1972, p. 94 e 95). 
É necessário acrescentar que Clozier, nestas mesmas páginas, diz que a geografia geral, por sua vez, pode ser dividida em duas grandes sub-áreas de conhecimento: geografia física e geografia humana.

- Françoise Cribier et al., em 1967, trazem uma conceituação resumida e original:

Distinguem-se dois aspectos complementares da geografia: a geografia geral e a geografia regional. A primeira classifica os tipos e busca as regras às quais obedecem os processos: ela estuda, por exemplo, o habitat rural, o modelo glaciar. A segunda, que é "mais uma arte do que uma ciência", pesquisa aquilo em que cada paisagem, cada combinação regional é original (CRIBIER et al., 1967, p. 17).

Tendo em vista esta dupla abordagem geográfica, e não negligenciado o fato de que a interação entre as duas abordagens é essencial para o progresso da geografia, dois eixos de reflexão e pesquisa foram definidos, a fim de que os geógrafos gregos pudessem ser classificados epistemologicamente. Assim, seguindo o princípio da minimização das diferenças e da maximização das semelhanças, o quadro 1 foi construído, para se dar coerência e estrutura ao conjunto diferenciado de geógrafos da Grécia antiga:

\section{Quadro 1 - Os dois eixos da Geografia clássica grega e as sínteses}

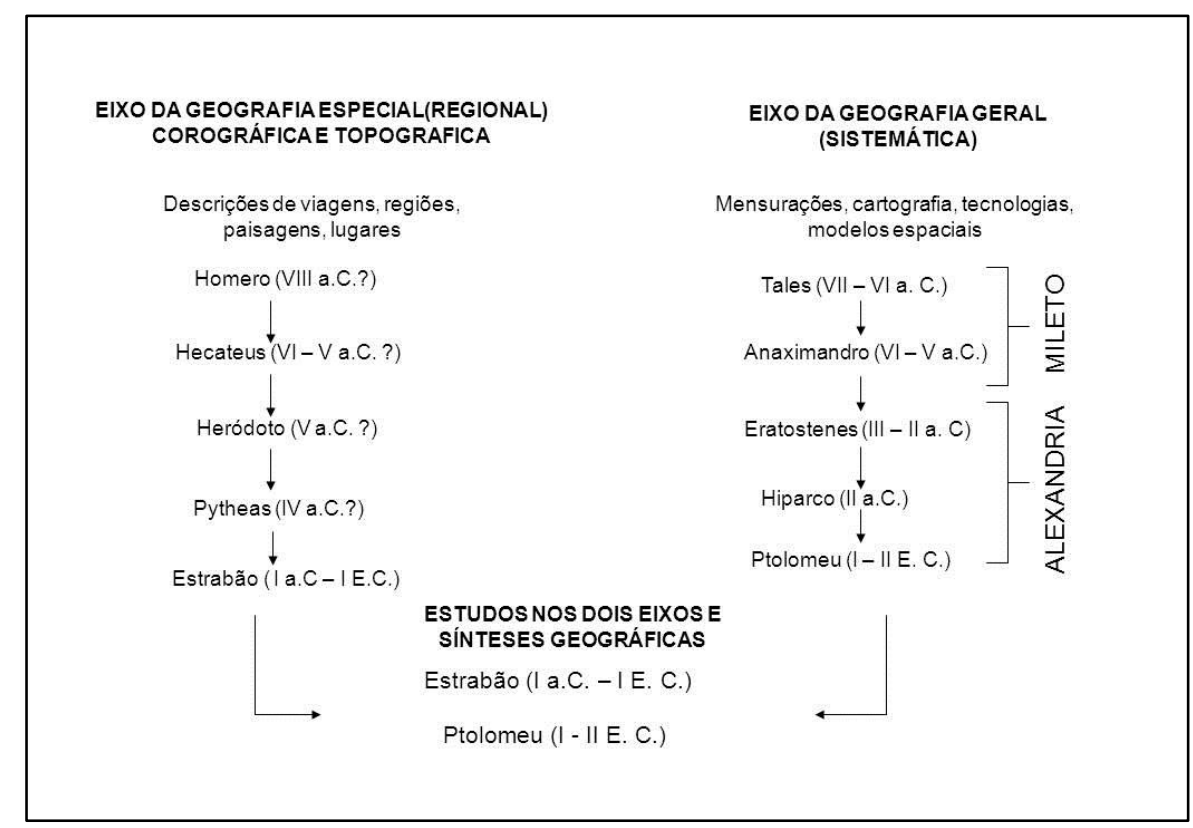

Fonte: Amorim Filho, 2011/2012.

Considerando-se este quadro, alguns nomes são citados entre aqueles que tiveram influência maior sobre os geógrafos árabe-muçulmanos medievais: Eratóstenes, Hiparco e Ptolomeu, no eixo da geografia geral; Homero, Heródoto e Estrabão, no eixo da geografia corográfica (regional). 
Dentro desta mesma lógica, os principais nomes da geografia árabe-muçulmana medieval foram também agrupados em dois eixos, tal como explicitado no quadro 2 :

\section{Quadro 2 - Os dois eixos da geografia no islã medieval e as sínteses}

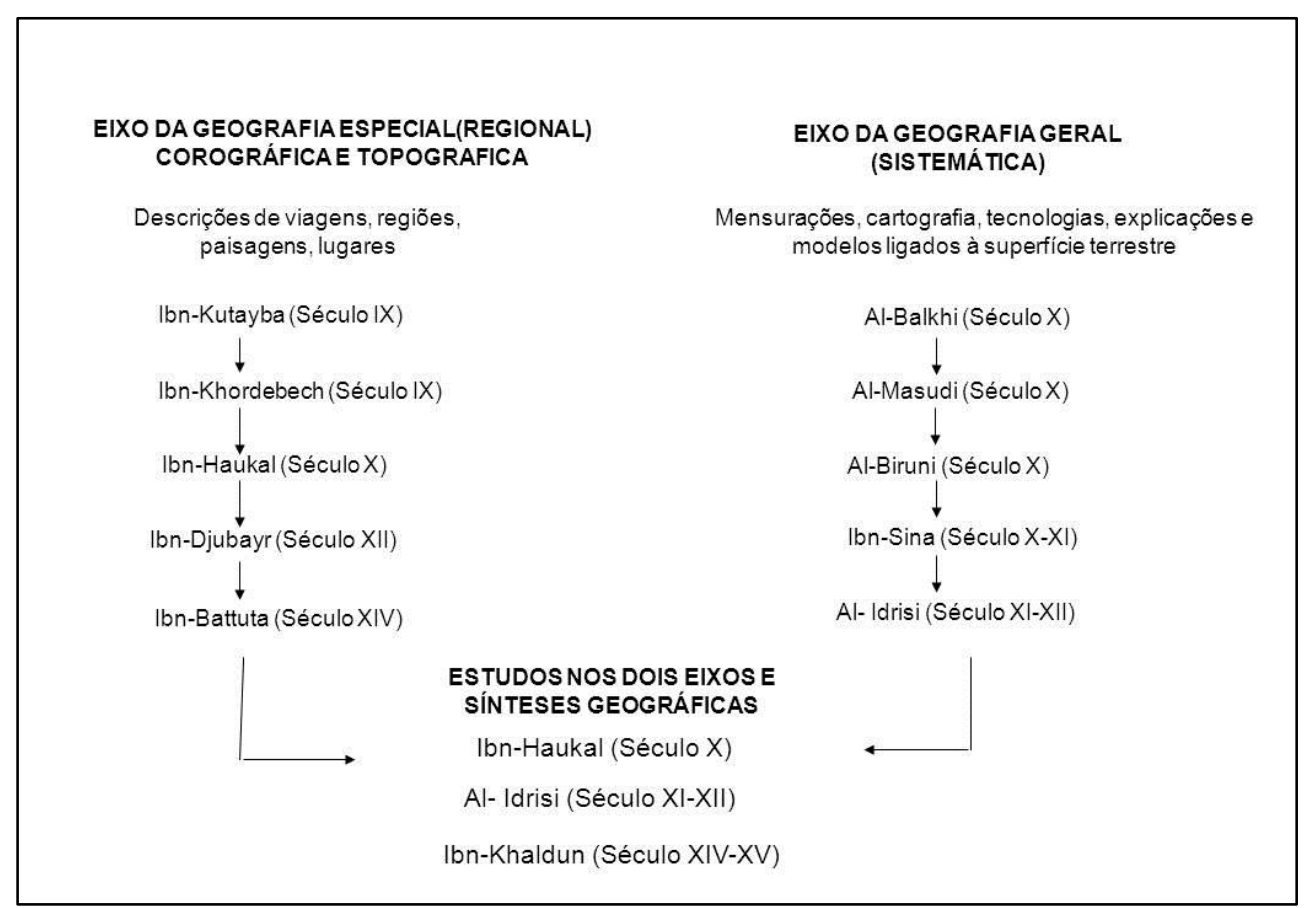

Fonte: Amorim Filho, 2011/2012.

Entre esses geógrafos árabe-muçulmanos, alguns tiveram destaque especial pelas dimensões, alcance e originalidade de suas contribuições. Na seção seguinte, um estudo epistemológico comparativo será elaborado entre um geógrafo que coordenou e produziu possivelmente o trabalho que mais se aproximou do ideal científico preconizado pelos gregos clássicos e adotado pelos pesquisadores do eixo da geografia geral ou sistemática: Idrisi, com seu Kitab Rujar (escrito a mando de e em homenagem ao príncipe normando da Sicília, Roger); e o viajante que mais países, lugares e paisagens visitou na Idade Média, também conhecido como "o viajante do Islã": Battuta, com sua Rihla (relato de viagem ditado ao literato Ibn Juzay).

\section{UMA EPISTEMOLOGIA COMPARATIVA ENTRE O KITAB DE IDRISI E A RIHLA DE BATUTA}


As duas obras que serão aqui analisadas estão, na opinião unânime de historiadores, geógrafos e outros intelectuais interessados na Idade Média, entre as mais representativas das grandes contribuições dadas à geografia por geógrafos árabe-muçulmanos. Elas estão, igualmente, em duas posições epistemológicas fundamentais para se entender a evolução do pensamento geográfico: primeiramente, fazem parte daqueles trabalhos que se situam claramente na continuidade dos principais eixos de pesquisa iniciados pelos geógrafos da Grécia clássica, mais explicitamente na obra de Idrisi, mas, certamente também na de Battuta; em seguida, mesmo que as primeiras traduções totais dessas obras só tenham sido feitas no século XIX por pesquisadores franceses, o que era conhecido delas ao final do Medievo contribuiu, provavelmente, para o desenvolvimento da geografia ocidental principalmente no início da Renascença.

\subsection{O Kitab de Idrisi}

O trabalho de Idrisi tem, originalmente, um título longo: "Divertimento para aquele que é apaixonado pela peregrinação através do mundo". Este título foi posteriormente resumido para Kitab Rujar, ou seja, "O livro de Roger”, mas muitos de seus leitores se referem a ele simplesmente como Kitab ${ }^{3}$.

Frances C. Gies assim descreveu as condições em que o livro nasceu:

No ano 1138, no palácio real de Palermo, Sicília, acontecia a reunião longamente esperada entre um rei cristão atípico e um distinto intelectual muçulmano. [...]. Quase imediatamente os dois homens começaram a discutir o projeto para o qual o intelectual tinha sido convidado para vir da África do Norte: a criação do primeiro mapa, preciso e científico, de todo o mundo conhecido. O monarca era Roger II, rei da Sicília, e seu distinto convidado, o geógrafo árabe Al- Idrisi. Nascido em Ceuta, Marrocos, na borda do estreito que separa este país da Espanha, Al-Idrisi estava, então, perto dos 40 anos. Depois de estudar em Córdoba, na Espanha islâmica, ele tinha gasto alguns anos em viagens, cobrindo a extensão do Mediterrâneo, de Lisboa a Damasco. [...] No decorrer de suas jornadas, ele tinha descoberto sua real paixão: a geografia (GIES, s/d, p. 1).

A leitura do texto organizado, comentado e apresentado por Bresc e Nef permite uma primeira e fundamental constatação: embora a autoria do livro seja sempre atribuída a Idrisi, a concepção, os objetivos, o método e as técnicas, enfim, o projeto de todo o trabalho é atribuído a Roger II pelo próprio Idrisi na introdução à obra, talvez apenas como homenagem ao monarca.

\footnotetext{
${ }^{3}$ Henri Bresc e Annliese Nef, que organizaram a edição de 1999 da tradução do Kitab que usamos como fonte principal do presente texto, informam que o livro de Idrisi só teve uma tradução para o Francês, feita pelo chevalier Jaubert e publicada pela Imprensa Real, entre 1836 e 1840 (BRESC et NEF, 1999, p. 7)
} 
Uma boa parte da coleta de informações foi assim conduzida por Idrisi, de acordo com Bresc e Nef:

[...] Ele partiu dos livros da geografia clássica árabe, depois ele interrogou os sábios, neste caso sem resultados. Ele fez vir à corte viajantes experimentados e ele os interrogou em conjunto, depois um de cada vez por intermédio de um intérprete, e rejeitou as informações contraditórias. Desejoso de se assegurar sobre a veracidade dos dados concordantes, ele desenhou um mapa graduado em uma prancheta, com a ajuda de um compasso de ferro. Posteriormente, ele mandou gravar sobre a esfera de prata este modelo, do qual o livro é a ilustração, e ele é provavelmente o original do mapa-mundi circular que acompanha cada manuscrito. O Kitab desenvolve, então, tudo que o mapa não podia traduzir: a descrição da natureza, as distâncias, as colheitas, as construções, as fabricações, os comércios, as maravilhas (BRESC et NEF, 1999, p. 19 e 20).

Para localizar as divisões zonais dos territórios que são objeto de suas descrições detalhadas, Idrisi utiliza o famoso quadro dos Climatas, desenvolvido por vários e sucessivos pensadores da Grécia clássica, e aperfeiçoado por Ptolomeu (Quadro 3).

\section{Quadro 3 - Localização das províncias no Kitab, a partir dos “Climatas” dos}

\section{geógrafos gregos clássicos}

\begin{tabular}{|c|c|c|c|c|c|c|c|c|c|c|}
\hline & $\mathbf{1}$ & $\mathbf{2}$ & $\mathbf{3}$ & $\mathbf{4}$ & $\mathbf{5}$ & $\mathbf{6}$ & $\mathbf{7}$ & $\mathbf{8}$ & $\mathbf{9}$ & $\mathbf{1 0}$ \\
\hline VII & $\begin{array}{c}\text { Irlande } \\
\text { Écosse }\end{array}$ & Angleterre & $\begin{array}{c}\text { Norvège } \\
\text { Danemark }\end{array}$ & Finmark & $\begin{array}{c}\text { Russie } \\
\text { Comanie }\end{array}$ & Bulghar & Basjirt & Sisiân & $\begin{array}{c}\text { Gog et } \\
\text { Magog }\end{array}$ & Océan \\
\hline VI & Bretagne & $\begin{array}{c}\text { France } \\
\text { Allemagne }\end{array}$ & $\begin{array}{c}\text { Bohème } \\
\text { Hongrie }\end{array}$ & $\begin{array}{c}\text { Macédoine } \\
\text { Pologne }\end{array}$ & Bulgarie & Pont & Caspienne & Simrîq1 & Turcs & \\
\hline V & $\begin{array}{c}\text { Gascogne } \\
\text { Galice }\end{array}$ & $\begin{array}{c}\text { Allemagne } \\
\text { Provence } \\
\text { Italie }\end{array}$ & $\begin{array}{c}\text { Calabre } \\
\text { Dalmatie }\end{array}$ & $\begin{array}{c}\text { Slavonie } \\
\text { Romanie }\end{array}$ & Anatolie & $\begin{array}{c}\text { Arménie } \\
\text { Azerbaìdjan }\end{array}$ & Caspienne & $\begin{array}{c}\text { Aral } \\
\text { Khwarizm }\end{array}$ & Kimakie & Turcs \\
\hline IV & $\begin{array}{c}\text { Andalus } \\
\text { Maghreb }\end{array}$ & Mer & Sicile & $\begin{array}{c}\text { Pélopon- } \\
\text { nèse }\end{array}$ & $\begin{array}{c}\text { Chypre } \\
\text { Syrie }\end{array}$ & $\begin{array}{c}\text { Irâq } \\
\text { Jibal }\end{array}$ & Khurâsân & $\begin{array}{c}\text { Tran- } \\
\text { soxiane }\end{array}$ & Kirghiz & Kimakie \\
\hline III & Maghreb & Ifriqîyya & Libye & $\begin{array}{c}\text { Delta } \\
\text { Égypte }\end{array}$ & $\begin{array}{c}\text { Palestine } \\
\text { Arabie }\end{array}$ & $\begin{array}{c}\text { Irak } \\
\text { Khuzistan } \\
\text { Fars }\end{array}$ & $\begin{array}{c}\text { Fars } \\
\text { Kirman }\end{array}$ & $\begin{array}{c}\text { Séistan } \\
\text { Ghawr } \\
\text { Tibet }\end{array}$ & $\begin{array}{c}\text { Tibet } \\
\text { Turcs }\end{array}$ & Kimakie \\
\hline II & Sahara & Sahara & Sahara & Égypte & Mer Rouge & $\begin{array}{c}\text { Arabie } \\
\text { Yémen }\end{array}$ & $\begin{array}{c}\text { Sind } \\
\text { Inde }\end{array}$ & Inde & Chine & Chine \\
\hline I & $\begin{array}{c}\text { Takrur } \\
\text { Lamlam }\end{array}$ & Ghâna & Kawar & $\begin{array}{c}\text { Nubie } \\
\text { Abyssinie }\end{array}$ & Abyssinie & Yémen & Zanj & $\begin{array}{c}\text { Sofala } \\
\text { Ceylan }\end{array}$ & $\begin{array}{c}\text { Insulinde } \\
\text { Champa }\end{array}$ & $\begin{array}{c}\text { Mer } \\
\text { de Chine }\end{array}$ \\
\hline
\end{tabular}

Fonte: IDRISI, 1999, p. 21.

A abordagem de Idrisi utiliza uma descrição bastante detalhada e cuidadosa, dividida em duas partes: uma, introdutória e curtíssima; a outra, bastante extensa, cobrindo cada uma das sete grandes zonas (climatas) em que se dividia a superfície da Terra. Essa abordagem foi resumida pelo próprio Idrisi, como segue:

Nós terminamos a descrição sucinta do aspecto da terra, de sua divisão em Climatas, e aquela dos mares, dos quais nós descrevemos o início, o fim e a extensão, assim como os países e os povos que os margeiam. Nós mencionaremos os reinos que se encontram nelas, as estradas e caminhos, as 
distâncias em 'parasanges' (um parasange equivaleria a cerca de 5.250 m.), milhas e jornadas de navegação. Nós descreveremos seus rios, a profundidade de seus mares, os costumes de seus habitantes, seus desertos, tudo isso claramente, precisamente e em detalhes, com uma aplicação e um zelo extremos (IDRISI, em BRESC et NEF, 1999, p. 67 e 68).

Essa descrição pormenorizada, que poderia ser definida como pré-científica com base nas geografias dos séculos XIX e XX, pode ser encontrada na maior parte do Kitab, inclusive com a fidelidade a uma certa sequência temática, quando se trata de itinerários, rios e cidades. Um exemplo desse tipo de descrição geográfica pode ser visualizado no fragmento de texto seguinte:

Daí a Tlemcen, uma pequena jornada. Tlemcen é uma cidade muito antiga, protegida por uma cerca forte, cuja solidez é perfeita. Duas cidades foram reunidas e separadas do exterior por uma muralha. Seu território é irrigado por um rio que vem da montanha, chamado al-Sakharatayn ("das duas rochas"), onde se eleva uma povoação fortificada, construída pelos Masmûda antes da tomada de Tlemcen e que eles habitaram sem interrupção até a conquista da cidade. $\mathrm{O}$ rio passa a leste da cidade, faz rodar numerosos moinhos e irriga todas as culturas situadas em suas margens. Encontram-se aí cereais, cultivos e frutos em abundância (IDRISI, 1999 [Reedição da tradução do original do século XII, feita pelo Chevalier Jaubert, apresentada e anotada por BRESC e NEF, p. 155]).

Para se ter uma ideia do volume de informações contidas no texto de Idrisi é preciso se dar conta de que, cada climata foi dividido em dez seções geográficas, cada uma delas descritas com o detalhe possível (detalhamento que diminuía à medida que a seção descrita se afastava do Mediterrâneo!), de Ocidente para Oriente. Mas, isto não impede que o livro seja hoje celebrado como "a primeira geografia do Ocidente" medieval, nas palavras de Henri Bresc e Annliese Nef, na capa da edição de 1999, da tradução comentada da obra de Idrisi. Mas, nunca é demais lembrar que o livro propriamente só apareceu depois - como uma espécie de extenso comentário complementar - do estabelecimento de um mapa do mundo conhecido e de um globo terrestre, construído de prata, a pedido do rei Roger. Esta harmoniosa complementaridade entre o mapa e o livro de Idrisi foi assim percebida por Emmanuelle Tixier du Mesnil:

O livro se coloca como o complemento ou, mais justamente, o acompanhamento de um suporte gráfico, um planisfério de prata no qual teria sido gravado um mapa do mundo, esquematizado previamente pelo rei normando sobre uma prancheta. [...]. A minuciosa coleta de informações, realizada por cerca de quinze anos nos livros de geografia, junto aos viajantes e conhecedores do terreno, a triagem rigorosa entre o improvável e o verídico, dão nascimento, em um primeiro tempo, a uma representação gráfica, aquela que o rei Roger, ou o geógrafo, pouco importa, desenha em

\footnotetext{
${ }^{4}$ Nota do autor deste artigo.
} 
uma prancheta. [...] Idrisi afirma, então, que o mapa vem primeiro, e justifica sua existência em razão da importância das obras anteriores de dar conta da diversidade e da complexidade do mundo. A partir deste mapa, um planisfério de prata é executado pelos melhores artesões. O livro vem em um segundo momento. Ele acompanha o planisfério e retoma em parte as informações que este último apresentava à vista, acrescentando-lhes algumas indicações relativas às atividades e aos costumes das diferentes populações. O livro reforça mesmo a primazia do suporte gráfico pois que ele contém, ao fim de cada capítulo, o mapa correspondente ao espaço descrito. São, assim, uns setenta mapas que vem inserir-se no seio da obra, ilustrando as dez seções que cada um dos sete climatas do mundo comporta. Estes mapas são todos de mesmo formato, portanto de escalas diferentes, pois os climatas não são de dimensões iguais (DU MESNIL, 2011, p. 58 e 59).

\section{Figura 1 - O mapa de Idrisi}

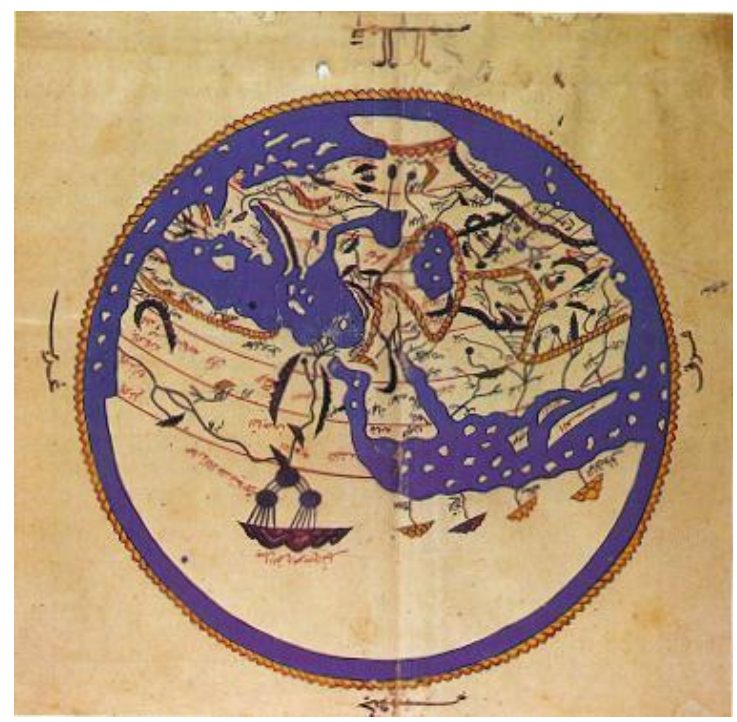

Fonte: http://www.juntadeandalucia.es/averroes/ 14700596/departamentos/imagenes/alidrisimap1.jpg

\section{Figura 2 - O planisfério de Roger e Idrisi}

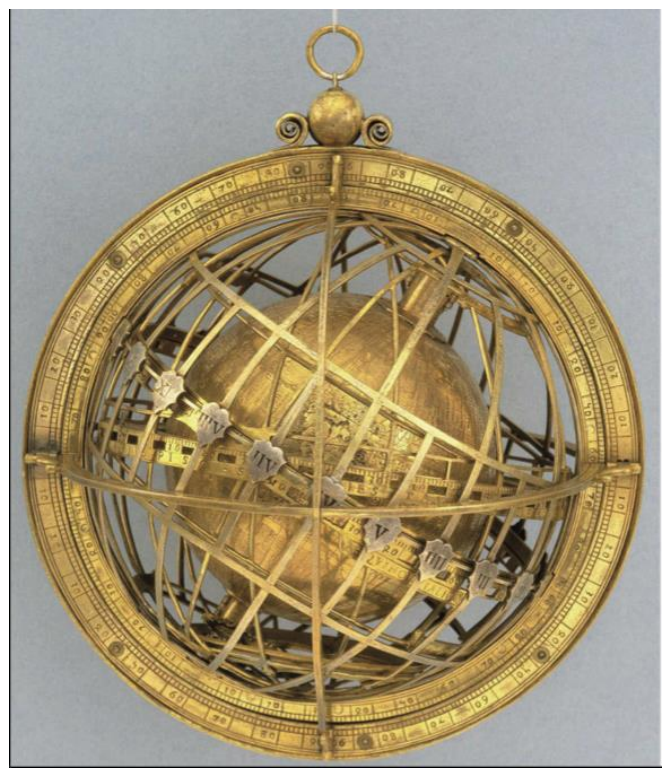

Fonte: http://cartographic-images.net/Cartographic_Images/314_Lenox_Globe_files/droppedImage_11.png 
As breves informações e reflexões sobre o Kitab, de Idrisi, são todavia bastante suficientes para estabelecer dois pontos: o primeiro é o de que esta obra se coloca na sequência da tradição mais científica da geografia desde os gregos, pois que, além do mapa e do planisfério, o livro tenha uma sequência de descrições de seções das grandes zonas geográficas denominadas, desde os gregos e romanos antigos, Climatas; o segundo é seu caráter epistemologicamente distinto da obra que, cerca de dois séculos depois, Ibn-Battuta ditou para seu tradutor Ibn-Juzay.

\subsection{A Rihla de Battuta}

Antes de uma reflexão sobre o valor geográfico da obra de Battuta, é preciso pensar sobre as razões pelas quais uma obra elaborada na segunda metade do século XIV, traduzida em sua integralidade apenas em meados do $\mathrm{XIX}^{5}$, é resgatada e passa a receber maior atenção particularmente dos historiadores e dos geógrafos no final do século XX e neste início do século XXI.

Pode-se afirmar que, sem o crescimento da chamada Geografia Humanista e/ou Cultural (e de um movimento parecido na História) durante a segunda metade do século XX, a Rihla de Battuta continuaria a ser bem conhecida dos intelectuais muçulmanos e apenas marginalmente vista pelos geógrafos ocidentais. A literatura e as artes em geral, embora toleradas pelas geografias alemã e francesa clássicas, não são bem vistas pelos adeptos dos paradigmas neopositivistas e neomarxistas, com forte presença nas academias de vários países ocidentais (inclusive do Brasil), a partir dos anos 1960 e 1970.

Michel Collot faz algumas reflexões bastante relevantes sobre a inclusão da literatura no pensamento geográfico e dos espaços geográficos na literatura:

De uns vinte anos para cá, um número importante de trabalhos têm sido consagrados à inscrição da literatura no espaço e/ou à representação dos lugares nos textos literários. Eles não poderiam deixar de cruzar o interesse crescente dos geógrafos pela literatura. [...] O aumento do prestígio de uma geografia literária é inseparável da evolução das ciências do homem e da sociedade que têm-se mostrado, pelo menos há meio século, cada vez mais atentas à inscrição dos fatos humanos e sociais no espaço. [...] É no quadro dessa mutação epistemológica geral que é preciso situar o interesse crescente

\footnotetext{
${ }^{5}$ No primeiro volume da edição de 1997 (Paris, La Découverte/Poche. Littérature de Voyage) das viagens de Battuta, S. Yerasimos, autor de uma longa introdução (59 p.) e de 329 anotações, assim se refere à primeira tradução da obra de Battuta: "Ibn Battuta, conhecido e apreciado no conjunto do mundo islâmico, (seu) texto deu lugar a numerosas cópias manuscritas, que foram reunidas, comparadas, traduzidas em francês e publicadas pela primeira vez em 1853-1858 por C. Defremery e B. R. Sanquinetti. [...] Este texto será o único a ser reproduzido na França (YERASIMOS, 1982/1997, p. 25).
} 
pelas questões de geografia literária. [...] E as pesquisas que se multiplicam sobre um gênero como o relato de viagem implicam numa reavaliação das relações entre literatura e geografia. [...] Este interesse se inscreve na corrente em favor de uma geografia humanista, que se desenvolveu a partir dos anos 1970 em relação à evolução de uma disciplina que, favorecendo o aperfeiçoamento dos meios técnicos, matemáticos e informáticos colocados a sua disposição, tinha tendência a privilegiar uma análise objetiva e abstrata do espaço geográfico em detrimento de sua dimensão humana e sensível. Observa-se, então, uma convergência notável entre as duas disciplinas, os geógrafos encontrando na literatura a melhor expressão da relação concreta, afetiva e simbólica que une o homem aos lugares, e os literários mostrandose, de seu lado, cada vez mais atentos ao espaço onde se desenrola a literatura (COLLOT, acessado em 20/06/2013, p. 1 e 2).

Nessa reaproximação, relativamente recente em termos de história do pensamento geográfico, entre geografia e literatura, não é todo o campo literário que atrai o interesse dos geógrafos. Certos gêneros, como por exemplo, as chamadas literaturas essencialistas, intimistas, psicológicas etc., naturalmente polarizam bem menos os geógrafos do que as literaturas de viagem, denominadas por pesquisadores como o francês Michel Chevalier de “géographies parallèles" ou "paragéographies", em oposição à "géographie" propriamente dita, científica, abstrata e universitária. O que a geografia humanista tornou possível resgatar como objeto de pesquisa e de interesse epistemologicamente válido para professores e/ou pesquisadores acadêmicos, assim como para qualquer ser humano que se interessa pela superfície terrestre enquanto morada do homem, são essas "parageografias" e, dentre elas, em um lugar muito especial desde os tempos dos geógrafos-viajantes da Grécia antiga, as "literaturas de viagem". E, na geografia humanista, as literaturas de viagens vão deixando gradualmente de ser "parageografias", ou "geografias paralelas", para tornarem-se uma das formas de se produzir e usar conhecimento geográfico mais valorizadas neste alvorecer de milênio.

A respeito da literatura de viagem, Odile Gannier chama primeiramente a atenção para a pluralidade do corpus principal que a compõe, sintetizado no quadro seguinte.

\section{Quadro 4 - Uma tipologia das Literaturas de Viagem: um corpus variado}

\begin{tabular}{|l|l|}
\hline \multicolumn{1}{|c|}{ TIPOS } & \multicolumn{1}{|c|}{ EXEMPLOS E/OU CARACTERÍSTICAS } \\
\hline 1 - DIÁRIOS DE BORDO: & $\begin{array}{l}\text { Colombo, Wallis, Bougainville, Cook (Relembremos que, em uma expedição como } \\
\text { aquela de Bougainville, cada oficial }[\ldots] \text { devia escrever a própria versão do diário de } \\
\text { bordo }[\ldots]] .\end{array}$ \\
\hline 2 - LIVRO DE BORDO OFICIAL: & Pigafetta (para Magalhães); Challe são escrivães de barco. \\
\hline $\begin{array}{l}\text { 3 - "CARNETS" (CADERNETAS), } \\
\text { VIAGEM": }\end{array}$ & Frequentemente a primeira forma de um relato, que será reescrito. \\
\hline
\end{tabular}




\begin{tabular}{|l|l|}
\hline 4 - "SOUVENIRS” DE VIAGEM: & $\begin{array}{l}\text { Produtos de uma redação posterior ao retorno; são, em princípio, verdadeiros; em } \\
\text { realidade, mais ou menos arranjados em função dos esquecimentos, do prisma que resulta } \\
\text { do bom e do mau souvenir, da documentação consultada após o regresso. }\end{array}$ \\
\hline 5 - CARTAS: & Vespúcio, Colombo, Saussure, cartas dos Jesuítas. \\
\hline 6 - RELATÓRIOS DE MISSÕES: & Breton, Labat, Du Tertre... \\
\hline HISTÓRICO: & Villehardoin, La Conquête de Constatinople... \\
\hline $\begin{array}{l}\text { 8 - RELATOS (“Récits") } \\
\text { ROMANCEADOS (...): }\end{array}$ & $\begin{array}{l}\text { Chateaubriand (voyage en Amérique, Itinéraire de Paris à Jérusalem...), Sterne (Voyage } \\
\text { sentimental), Michaux (Un barbare en Asie...), etc. }\end{array}$ \\
\hline 9- VIAGENS IMAGINÁRIAS & $\begin{array}{l}\text { Homère (A odisséia), Stevenson, Jack London, Cendrars, Monfreid e, sobretudo, Jules } \\
\text { Verne (literatura de viagens, em que o relato é, pelo menos parcialmente, próximo do } \\
\text { real); de outro lado, Defoe (Robinson Crusoé), Swift, Rabelais, Edgar A. Poe, etc, em que } \\
\text { o relato se afasta do real... }\end{array}$ \\
\hline 10 - ROMANCES DE VIAGEM: & $\begin{array}{l}\text { Textos cujo cenário é uma viagem (...), sem que esta seja o tema essencial (Diderot, } \\
\text { Defoe [Moll Flanders], Prévost [Manon Lescaut]...). }\end{array}$ \\
\hline 11 - PRETEXTO EXÓTICO: & $\begin{array}{l}\text { Montesquieu (Lettres persanes), Voltaire (L'Ingénu, Candide, Zadig,...); autores mais } \\
\text { modernos, que só utilizam o viajante como pretexto, para justificar um olhar "decalé” } \\
\text { [“deslocado"]). }\end{array}$ \\
\hline
\end{tabular}

Fonte: GANNIER Odile, 2001, p. 7 (Quadro traduzido e adaptado por Oswaldo Bueno Amorim Filho/PUCMinas, 06/06/2013).

Dentre os onze tipos de literaturas de viagem, identificados no quadro acima por Gannier, o que mais nos interessa, no âmbito deste trabalho, é o de número 4, denominado "souvenirs de Voyage", que inclui os "recits de Voyage" ("relatos de viagem"), categoria na qual se encaixa muito bem a Rihla de Battuta. Para Gannier:

O relato de viagem supõe evidentemente uma realidade descrita, o "referente" (percurso, "coisas vistas", pessoas encontradas, costumes percebidos...), para o qual se coloca o problema da relação com o relato em si. Ele supõe, também, um sujeito que se expressa, mais frequentemente, na primeira pessoa mas, também, na terceira, pois o "herói viajante" não é forçosamente aquele que segura a pena. $\mathrm{O}$ texto se mostra, em geral, como eminentemente subjetivo. (...) Enfim, o relato de viagem supõe uma viagem de ida e, sobretudo, de volta, corolário da noção de périplo no sentido etimológico (perí-pleo significa navegar, voltando ao seu ponto de partida). Voltar à casa é, frequentemente, a condição material da escrita, ao mesmo tempo que o atestado de que realmente se viu o que se relata. As categorias essenciais do tempo e do espaço se impõem mais vivamente que em outros gêneros (GANNIER, 2001, p. 5 e 6).

A Rihla se apresenta como um dos quatro principais tipos de deslocamentos, ou viagens, realizados pelos muçulmanos e encorajados pela religião islâmica. Methal R. Mohammed, em sua tese de doutorado (Texas A\&M University), caracteriza, como segue, esses quatro tipos fundamentais de viagens no Islã:

O Islã, como religião e prática social, encoraja a mobilidade por meio de diferentes formas de viagens. Uma dela é a hijra (migração), ou viagem de terras não-muçulmanas (dar al-Kufr) para terras muçulmanas (dar al-Islam). Outra forma de viagem é a hajj, a peregrinação a Meca, um dos cinco 
pilares do Islã, para muçulmanos que têm recursos para fazê-la. Uma terceira forma é a ziyarat, ou visita aos lugares sagrados, e a quarta é al-rihla, ou viagem em busca de conhecimento. Algumas jornadas de muçulmanos podem combinar duas ou mais formas de viagens, como os viajantes muçulmanos medievais que combinavam hajj e al-rihla em suas jornadas (MOHAMMED, 2011, p. 36).

No século VIII, as viagens dos muçulmanos começam a ter entre outros, novos objetivos, além de simples deslocamentos de um lugar para outro: de um lado, as viagens passam a ser um fator fundamental de enriquecimento intelectual para quem viaja, tal como prescreveram o Profeta e o próprio Al-Corão; de outro lado, essas viagens podem fornecer informações preciosas para a redação das 'Rihlas", relatos de viagens que, não somente enriquecem o conhecimento geográfico das diferentes regiões conhecidas da Terra, como, também, contribuem para desenvolver entre os vários povos que ocupam o Islã, uma ideia e um sentimento de pertencimento a uma comunidade religiosa grandiosa (TOUATI, 2000).

Assim, a tradição das viagens para a obtenção de conhecimento, sabedoria e santidade se instala no século VIII entre os intelectuais e líderes religiosos muçulmanos, transformandose também em gênero literário, entre os séculos X e XII (BISSIO, 2012), estendendo-se, sem descontinuidades importantes, até o fim da Idade Média.

De acordo com Houari Touati (Paris, 2000), as viagens de pelo menos quatro tipos de pensadores muçulmanos deram origem a rihlas valorizadas por todos: os geógrafos (ou “autores de obras de geografia”); os juristas, os filólogos e os místicos. É preciso não se esquecer de que os autores dessas rihlas passam a ter o respeito e a admiração não apenas dos dirigentes e intelectuais mas, igualmente, de grande parte da comunidade muçulmana que toma conhecimento de suas obras.

A obra de Battuta (século XIV) é, desse modo, a mais famosa de uma série de rihlas e apesar de descrever principalmente o mundo islâmico de então, transcende, por seu valor geográfico, histórico e literário, os limiares da religião islâmica e dos povos islamizados.

De acordo com os analistas e comentaristas, o trabalho de Battuta se inspirou em outras rihlas, em especial a de Ibn Yubair (século XII) que, além de servir de modelo para a Rihla de Battuta, forneceu informações importantes para este último. Bissio (2012) lembra, ainda, outro tipo de influência de Yubair sobre Battuta:

A rihla de Ibn Yubair, apelidado pelos cristãos de "o Valenciano", é tida como exemplo, uma vez que lhe é reconhecida uma grande beleza literária. Seria também essa a razão pela qual um homem letrado como Ibn Battuta, que exerceu o cargo de cádi em várias partes do mundo e, portanto, não teria dificuldades de escrever pessoalmente as suas memórias, teria optado por ditar ao poeta Ibn Juzayy suas aventuras de quase trinta anos pelo domínio do Islã (BISSIO, 2012, p. 182). 
Ibn Battuta é originário de uma família bérbere, tendo nascido em 1304, em Tanger (hoje Marrocos), cidade situada na margem meridional do Estreito de Gibraltar, vindo a falecer no ano de 1369, após uma vida plena de viagens e aventuras. O mapa da figura 3 apresenta as rotas presumíveis dessas viagens, comparados àquelas realizadas, algumas décadas antes, por outro dos maiores viajantes-exploradores medievais, Marco Polo.

Apesar do mapa representar o alcance imenso, em termos espaciais, das viagens de Battuta, a descrição de Daniel Nordman (1988), mesmo sucinta, mostra a grandiosidade dessas jornadas:

Battuta [...] partiu com a idade de 25 anos, para a peregrinação a Meca e percorreu a terra pela África do Norte, o Egito e Arábia, Pérsia, Iraque, Mar Vermelho e ao longo da costa africana, pela Ásia Menor e Mar Negro, estepes da Ásia Central, Afeganistão, Índia, Ilhas Maldivas, Bengala, Sumatra e China, voltando pelo Oceano Índico, Bagdad, Síria e Egito, e realizou novamente a peregrinação a Meca. Ele chegou a Fès, em 1349, para partir, em seguida, para a Espanha e, depois, para o Mali. Em vinte e oito anos e uma dezena de viagens (...) ele fez cerca de cento e vinte mil quilômetros, nos territórios correspondentes a algo como quarenta e quatro países atuais (NORDMAN, D, em Resenha do livro de Ross E. Dunn, The Adventures of Ibn Battuta - A Muslin Traveler of the 14 th Century, 1986).

\section{Figura 3 - As viagens de Ibn Battuta e Marco Polo}

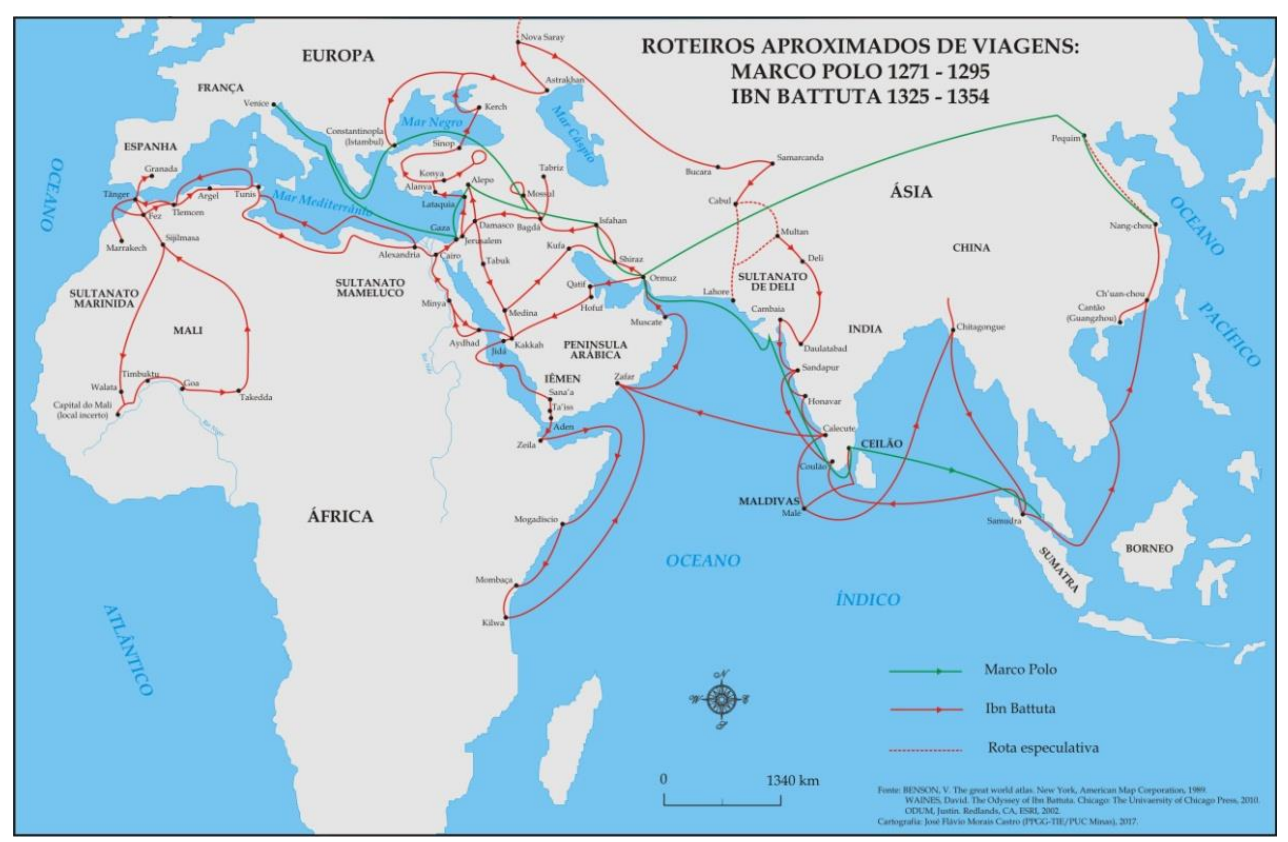

Fontes: WAINES, 2010; BENSON, 1989; ODUM, 2002.

Os temas principais tratados na Rihla de Battuta podem ser sintetizados e visualizados no quadro 5. 


\begin{tabular}{|l|l|}
\hline CIDADES PORTOS & $\begin{array}{l}\text { Extensão, população economia (em especial comércio), hierarquia, mesquitas, } \\
\text { monumentos, escolas (“madrassas”), hospedarias, asilos, etc... }\end{array}$ \\
\hline PEREGRINAÇÕES & $\begin{array}{l}\text { Sobretudo à cidade sagrada de Meca (descrita, por exemplo, em 100 páginas do } 1^{\circ} \text { volume, } \\
\text { da obra apresentada e comentada por S. Yerasimos em 2010), mas, também, a vários } \\
\text { pequenos lugares de perigrinação (sepulcros, locais de milagres, de batalhas, etc). }\end{array}$ \\
\hline ASPECTOS DA GEOGRAFIA FÍSICA & Desertos, rios, montanhas, vales, mares, etc... \\
\hline ITINERÁRIOS E DISTÂNCIAS & Sobretudo entre as centenas de cidades visitadas e descritas por Battuta... \\
\hline RANTOS, SÁBIOS, LIDERES & Na maior parte (quase a totalidade) muçulmanos... \\
\hline ASSUNTOS DE GEOPOLÍTICA & Guerras, batalhas, conspirações, revoluções, alianças (e reversão de alianças), impérios, etc. \\
\hline HOMENS, DINASTIAS E FAMÍLIAS & $\begin{array}{l}\text { Frequentemente descrições laudatórias, mas, em alguns casos (como o do sultão } \\
\text { Muhammad Tuglhuk), também com denúncias de tiranias cruéis... }\end{array}$ \\
\hline ASSUNTOS PESSOAIS & Cargos e funções, títulos, bens, casamentos, esposas, filhos, doenças, dificuldades, etc... \\
\hline ANEDOTAS & $\begin{array}{l}\text { Pequenas estórias, às vezes à margem da sequência narrativa principal, com finalidade ética } \\
\text { ou de divertimento, ou ainda as duas juntas. }\end{array}$ \\
\hline RELIGIÃO MUÇULMANA & $\begin{array}{l}\text { Umma (comunidade de todos os muçulmanos), Alcorão, Sunna, escolas jurídicas, correntes } \\
\text { de interpretação, infiéis, idólatras, etc. É preciso lembrar que a religião muçulmana é o pano } \\
\text { de fundo presente em toda a obra. }\end{array}$ \\
\hline $\begin{array}{l}\text { MORADIAS, } \\
\text { PROPRIEDADES }\end{array}$ & $\begin{array}{l}\text { Sobretudo dos inúmeros anfitriões e benfeitores de Battuta... } \\
\text { também é recorrente na Rihla de Battuta, pois que se trata de uma das condições de } \\
\text { sobrevivência de todo viajante... }\end{array}$ \\
\hline VULINÁRIA
\end{tabular}

Fonte: Oswaldo Bueno Amorim Filho/2013.

Se, no caso do Kitab de Idrisi, as fontes das informações utilizadas pelo autor estão definidas já no próprio Prólogo, no caso da Rihla de Battuta, há apenas uma referência bastante geral e sucinta na brevíssima Introdução feita, com estilo floreado, por Ibn Juzay, pelo menos na versão editada por Tim Mackintosh-Smith, edição de 2003:

Ele (Ibn Battuta), abarcou a terra com uma mente atenta e viajou através de suas cidades com olhar observador, e investigou as diversidades das nações e penetrou nos modos de vida de árabes e não-árabes, desde então abandonando o bastão dos muito-viajados nesta Sublime Residência. Uma bondosa orientação foi transmitida no sentido do que ele pudesse ditar um relato das cidades que ele tinha visto em suas viagens, e dos eventos interessantes que tinham permanecido em sua memória, e que ele pudesse falar daqueles dirigentes de países que ele havia encontrado, de seus eminentes homens do saber, e de seus piedosos santos (MACKINTOSHSMITH [ed.], 2003, p. 1).

Em outras partes desta mesma introdução, Ibn Juzay afirma ter feito, com uma linguagem polida, "uma compilação" daquilo de mais interessante que lhe fora ditado por Ibn Battuta, "o mais confiável e verdadeiro viajante".

É fato que, nesse longo texto, Battuta se utiliza com referência explícita ou não, das contribuições de vários viajantes anteriores e contemporâneos como, por exemplo, Ibn Yubair (especialmente), Ibn Hauqal, Aly Arrazy, Al-Abdari, Ibn Fadl Allah al-Umeri, entre outros. 
Em função de certos exageros, ou da descrição de alguns fenômenos ou acontecimentos, considerados inverossímeis à época e, sobretudo, com a utilização de informações contidas nos relatos dos autores acima citados, nem sempre com créditos e referências que hoje são usuais, Ibn Battuta foi criticado como inverídico, ingênuo e, até mesmo, como plagiário e mentiroso. O que, aliás, aconteceu com quase todos os autores-viajantes da Idade Média, inclusive com seu quase contemporâneo, Marco Polo (Battuta inicia sua viagem um ano após a morte de Polo). David Waines sai em defesa de Battuta e, indiretamente, de outros viajantes medievais, com a argumentação seguinte:

Entretanto, finalmente e julgada pelos padrões da convenção medieval, na Europa ou no Oriente Médio, a acusação de plágio parece fora de propósito: empréstimos, reescritos ou reelaborações, e invenções em variadas roupagens eram práticas generalizadas e aceitas (WAINES, 2010, p. 21).

Após todas essas considerações contextuais e epistemológicas, bem próprias da academia, um mergulho direto no texto ditado a Ibn Juzay por Battuta é a etapa final da busca de entendimento dessa rihla.

O texto da Rihla de Battuta apresenta, em vários domínios, diferenças significativas em relação ao texto do Kitab de Idrisi: além de um estilo mais literário, a maior parte das descrições da Rihla inclui aspectos religiosos, que têm papel preponderante na narrativa e, em várias passagens, o maravilhoso, o sublime e o extraordinário também estão presentes. Os exemplos seguintes servem para ilustrar as constatações acima.

Uma descrição urbana de Battuta:

Eu saí de Emese (atual Homs) para ir à cidade de Hamah, uma das metrópoles mais nobres da Síria e uma de suas cidades mais admiráveis. Ela possui uma beleza resplandecente e uma graça perfeita; ela é envolvida por hortas e pomares, perto dos quais vêem-se rodas hidráulicas, que poderiam ser tomadas por globos celestes que giram. Ela é atravessada por um rio considerável, denominado Al'acy. Ela tem, também, um subúrbio chamado Almansouriyah, que é maior do que a própria cidade, e onde se vêem mercados muito frequentados e banhos magníficos.

Em Hamah, há muitos frutos, entre os quais aquele chamado damasco com amêndoa, pois, quando se quebra seu núcleo, encontra-se em seu interior uma amêndoa doce (BATTUTA, 1982, p. 176).

Uma descrição fluvial de Battuta:

O Nilo do Egito supera todos os rios da Terra pela tepidez de suas águas, a vasta extensão de seu curso e sua grande utilidade (para as populações ribeirinhas). As cidades e as aldeias se sucedem, com ordem, ao longo de suas margens. Não se conhece um rio cujas margens sejam tão bem cultivadas quanto aquelas do Nilo. Nenhum outro rio tem o nome de mar. (...) Lê-se, também, na tradição, que o Nilo, o Eufrates, o Seyhan (Yaxartes) e o Djeyhan (Oxus) estão todos entre os rios do paraíso. (...) A alguma distância do Cairo, o Nilo se divide em três ramos, os quais só podem ser 
atravessados por barco, tanto no inverno quanto no verão. Os habitantes de cada cidade possuem canais derivados do Nilo. Quando este rio está na cheia, ele enche esses canais, e eles se derramam, então, nos campos semeados (BATOUTAH, 1874, p. 54 e 55).

Uma anedota sobre o extraordinário, na Rihla de Battuta:

O sheik Abou Abd Allah Mohammed, filho de Khafif, tem um prestígio elevado entre os amigos de Deus. Foi ele que ensinou o caminho da montanha de Serendib, na ilha de Ceylão, a qual faz parte da Índia. (...) Conta-se que ele se dirigiu, um dia, à monhtanha de Serendib, acompanhado de cerca de trinta faquires. A fome os surpreendeu na estrada da montanha, em um lugar onde não havia nenhuma habitação, e eles se perderam de seu caminho. Eles pediram ao sheik que lhes permitisse pegar um filhote de elefante, que são numerosos neste lugar, e que, de lá, são transportados à capital do rei da Índia. Ele os proibiu de fazer isto; mas, a fome os venceu, e eles transgrediram a ordem do sheik, tomando um desses filhotes de elefantes, cotando-lhe a garganta e comeram de sua carne. O sheik recusouse a prová-lo. Quando eles adormeceram, na noite seguinte, os elefantes se reuniram de toda parte e vieram ao local onde os faquires se encontravam. Eles farejaram cada um dos faquires e mataram-no em seguida até que todos fossem exterminados. Eles farejaram também o sheik e não lhe fizeram nenhum mal. Um desses elefantes tomou-o em sua trompa, colocou-o no dorso e conduziu-o para onde se encontravam as habitações (BATTUTA, 1982, p. 420-421).

\section{CONSIDERAÇÕES FINAIS}

Para um estudioso da história do pensamento geográfico, já em pleno século XXI, ficam evidentes três pontos:

- as obras de Idrisi e de Battuta representam prolongamentos fiéis dos dois grandes eixos em que podem se dividir os principais geógrafos da Grécia antiga, não obstante os diferentes contextos sociais dos períodos em que viveram os dois autores muçulmanos;

- embora com abordagens diferentes em certos aspectos, como aliás este texto procura deixar claro, tanto Idrisi como Battuta produzem descrições verdadeiramente geográficas de vastas extensões da Terra;

- considerar apenas uma delas e desprezar a outra, em nome de uma pretensa superioridade em termos de legitimidade geográfica equivaleria à perda inestimável de uma das visões plurais que o homem vem construindo para descrever a Terra como sua morada.

A este respeito, as palavras de Yi-Fu Tuan, há mais de três décadas, são muito instrutivas: 
Tanto a arte quanto a ciência fazem abstrações do fluxo de (nossa) incipiente experiência. Elas segmentam a realidade e produzem representações do mundo. Essas representações, mais ou menos abstratas, paradoxalmente nos capacitam a compreender a concretude da experiência (TUAN, 1978, p. 196).

O exame do Kitab de Idrisi e da Rihla de Battuta, para além do interesse epistemológico, serve também para aumentar a admiração do geógrafo de hoje pelo papel desempenhado pelos geógrafos árabes-muçulmanos medievais, em uma das etapas mais cruciais da história do pensamento geográfico. O quadro 6 sintetiza algumas das principais contribuições dos dois sábios medievais e, ao mesmo tempo, fecha o presente estudo.

\section{Quadro 6 - As Geografias no Kitab (Isdrisi) e na Rihla (Battuta): uma síntese comparativa}

\begin{tabular}{|c|c|c|}
\hline & IDRISI (1100-1166?) & BATTUTA $(1304$ - 1369 $\rightarrow 1377 ?)$ \\
\hline Origem Geográfica & $\begin{array}{l}\text { Mazara (Sicília)? ou Ceuta (Marrocos)?; } \\
\text { Família Árabe / Andaluz; Dinastia Idríssida }\end{array}$ & $\begin{array}{l}\text { Tanger (Marrocos); Família } \\
\text { Berbere/Andaluz }\end{array}$ \\
\hline Obra/Finalidade & $\begin{array}{l}\text { "Kitab Rujâr" (Livro de Rogério da } \\
\text { Sicília); Descrição geográfica do mundo } \\
\text { (Século XII), em especial a Europa e o } \\
\text { Mediterrâneo. }\end{array}$ & $\begin{array}{l}\text { "Rihla" (Livro de viagens pelo mundo } \\
\text { islâmico-século XIV) }\end{array}$ \\
\hline Influências Principais & $\begin{array}{l}\text { Ptolomeu, Orosius (da Espanha pré- } \\
\text { islâmica); Azarchel (astrônomo hispano- } \\
\text { muçulmano); Geógrafos muçulmanos. }\end{array}$ & $\begin{array}{l}\text { Ibn-Jubayr, Ibn-Khoderbech, Ibn-Hauqal, } \\
\text { outros geógrafos/ viajantes árabe- } \\
\text { muçulmanos, por sua vez, influenciados } \\
\text { pelos gregos antigos. }\end{array}$ \\
\hline Papel da Religião & Presente, mas não fundamental ou decisiva. & $\begin{array}{l}\text { Causa inicial; orientação geral e uma das } \\
\text { finalidades maiores da viagem. }\end{array}$ \\
\hline Bases Epistemológicas & $\begin{array}{l}\text { Abordagens da geografia geral, zonal e } \\
\text { regional; inspiradas em Ptolomeu e com o } \\
\text { uso da Cartografia.Perspectiva científica. }\end{array}$ & $\begin{array}{l}\text { Abordagem corográfica, baseada em } \\
\text { métodos de geografia de viagens; relatos de } \\
\text { viagens. "Mundos vividos" / "geografias } \\
\text { experienciais". }\end{array}$ \\
\hline Características das informações & $\begin{array}{l}\text { Obras geográficas (greco-romanas e árabe- } \\
\text { islâmicas em especial dos viajantes). } \\
\text { Informações acumuladas no Reino da } \\
\text { Sicília; entrevistas guiadas com viajantes; } \\
\text { viagens pessoais. }\end{array}$ & $\begin{array}{l}\text { Observações de viagem (“campo") e uma } \\
\text { memória geográfica excepcional, para } \\
\text { relembrar as percepções e representações } \\
\text { geográficas do Battuta viajante. }\end{array}$ \\
\hline Mapas, figuras, tabelas, etc & Presentes, inclusive um "globo terrestre". & $\begin{array}{l}\text { Não presentes, mas, provavelmente, usados } \\
\text { pelo autor em suas viagens. }\end{array}$ \\
\hline Viagens & $\begin{array}{l}\text { De curto alcance em termos de extensão, } \\
\text { envolvendo sobretudo as regiões que } \\
\text { margeiam o Mediterrâneo meridional. }\end{array}$ & $\begin{array}{l}\text { De longo alcance, tanto em extensão, } \\
\text { quanto temporalmente. Visitou todos os } \\
\text { grandes centros urbanos e religiosos do Islã a } \\
\text { e alguns em suas margens não islamizadas, } \\
\text { por cerca de } 30 \text { anos, cobrindo algo em } \\
\text { torno de } 120.000 \mathrm{~km} \text {. }\end{array}$ \\
\hline
\end{tabular}

Fonte: Oswaldo Bueno Amorim Filho/2013.

\section{REFERÊECIAS}

BATOUTAH, Ibn. Voyages d'Ibn Batoutah (Traduction de C. Defremery et B. R. Sanguinetti). Paris, Société Asiatique/Imprimerie Nationale, MDCCCLXXXIV (Deuxième édition). 
BATTUTA, Ibn. Voyages - 3 volumes (Traduction de C. Defremery et B. R. Sanguinetti, 1858). Introductions et notes de Stéphane Yerasimos. Paris, La Découverte, 1997, 1409 p. (total des trois volumes).

BISSIO, Beatriz: $O$ mundo falava árabe: a civilização árabe-islâmica através da obra de Ibn Khaldun e Ibn Battuta. Rio de Janeiro, Civilização Brasileira, 2012, 347 p.

BLANCO, J. G.: Introducción General. ESTRABÓN: Geografía Livres I-II (Traducción y notas de J. L. García Ramón y J. García Blanco). Madrid, Editorial Gredos, 1991, 559 p.

BURLOT, Joseph. A Civilização Islâmica. Mem Martins, P. E. A., 1992, 304 p.

BUSH-JOSEPH, Kathleen. Ibn Jubayr: The Rihla. Senior Honors Seminar in History. Georgetown University. Repository: library.georgetown.edu/.../Bush-JosephTh... Acessado em 08/07/2013.

CHEVALIER, M. Géographie et Paragéographies. L'Espace Geographique, n 1, 1989, p. 517.

CLAVAL, Paul. Histoire de la Géographie. Paris, P. U. F., 1995, 127 p.

CLOZIER, René. Histoire de la Géographie. Paris, P. U. F., 1971 (1942), 128 p.

COLLOT, M. Pour une géographie littéraire. LHT Dossier (http://www.fabula.org./lht/8/index.php?id=242, acessado em 20/06/2013, pp. 1-14.

CRIBIER, F.; DRAIN, M.; DURAND-DASTÈS, F. Initiation aux exercices de Géographie Régionale. Paris, S. E. D. E. S., 1967, 209 p.

DU MESNIL, E. T. Le Livre et la Carte. Représentations de l'Afrique par Bakri (Xie siècle) et Idrisi (XIIe siècle). Paris, $C N C, \mathrm{n}^{\circ}$ 210, Décembre, 2011, pp. 53-61.

DUNN, R. E. The Adventures of Ibn Battuta. A Muslin Traveler of the $14^{\text {th }}$ Century. LondonSydney, Croom Helm, 1986, XVI - 357p.

GANNIER, O. La littérature de Voyage. Paris, Ellipses, 2001, 128 p.

GIES, F. C. http://environment-ecology.com/geographers-and-explorers/567-al-idirsi-androgers-b... Acessado em 08/04/2013.

HOLT-JENSEN, A. Geography: history and concepts. 4.ed. London: SAGE, 2009, 280 p.

HOURANI, Albert. Uma história dos povos árabes (Tradução de Marcos Santarrita). São Paulo, Companhia das Letras, 1994 (1991), 523 p.

IDRISI, Al. La première geographie de l'Occident (traduction du Chevalier Jaubert, 1840). Présentation par Henri Bresc et Annliese Nef. Paris, GF Flammarion, 1999, 516 p. 
KASAI, Yamato. Von Richthofen and Modern Geography - System and Unity of the geography Science em http://ir.library, tohoku.ac.jp/re/bitstream/10097/44999/1/AA0045945075367.pdf, acessado em 08/07/2013.

LYONS, Jonathan. A Casa da Sabedoria (Tradução de Pedro Maia Soares). Rio de Janeiro, Zahar, 2011, 294 p.

MACKINTOSH-SMITH, Tim (ed.). The Travels of Ibn Battutah. London, Picador, 2003 (1958, first edition), $325 \mathrm{p}$.

MARTIN, G, J. All Possible Worlds - A history of Geographical Ideas. Oxford, Oxford university Press, 2005, 605 p.

MOHAMMED, M. R. Al-Rihla and curriculum theory : a qualitative comparative study of contemporary and historical muslim travelers in search of knowledge. Texas A\&M University, 2011, 260 p. (Dissertation PhD).

NORDMAN, D. Commentaire de l'oeuvre de Ross E. Dunn, The Adventures of Ibn Battuta A Muslin Traveler of the 14th Century, 1986. In: Annales. Économies, Sociétes, Civilisations, Année 1988, vol. 43, n6, p. 1368-1370 (Persée, http: /www.persée,Fr; acessado em: $15 / 11 / 2017)$.

STRABÓN. Geografía (Traducción de J. L. García Ramón y J. García Blanco). Madrid, Editorial Gredos, 1991.

STEARNS, Peter N.: 2011, p. 2, em http://history-world.org./Islam.htm, acessado em 08/07/2013.

TOUATI, Houari. Islam et voyage au Moyen Âge. Histoire et anthropologie d'une pratique lettrée. Paris, Le Seuil, 2000, 344p.

TUAN, Y. F. Literature and Geography: implications for geographical research. LEY D. and SAMUELS M. S. (ed.): Humanistic Geography - Prospects and Problems. London, Croom Helm, 1978, 337 p.

VARENIUS, B. A compleat System of General Geography (translated by Mr. Dugdale). London, Stephen Austen, 1734 (2 vol.).

WAINES, David. The Odyssey of Ibn Battuta - Uncommon Tales of a Medieval Adventurer. Chicago, The University of Chicago Press, 2010, 226 p.

WELLS, H. S. Uma breve história do mundo (Tradução de Rodrigo Breunig). Porto Alegre, L \& PM Editores, 2011 (1922), 378 p.

Recebido em 01/12/2017.

Aceito em 12/12/2017.

Publicado em 02/01/2018. 